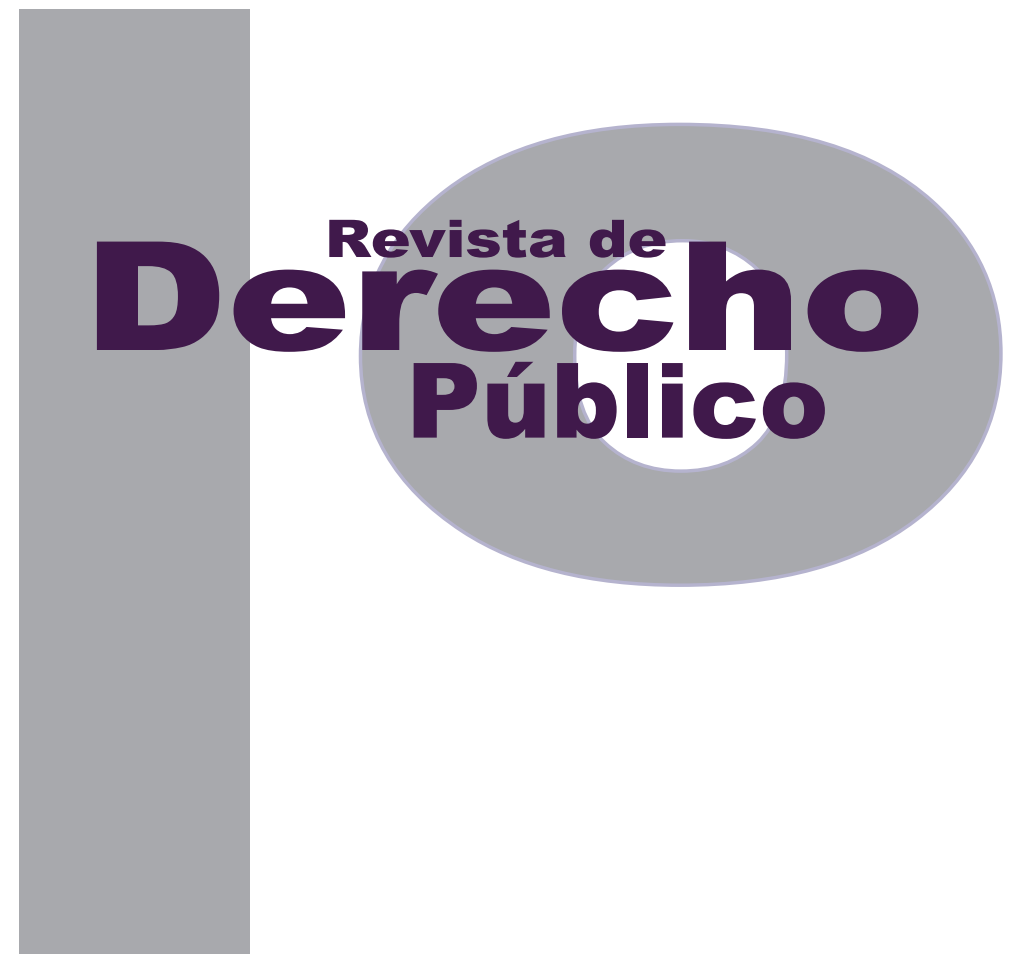

\title{
CÓMO ESCAPAR EL LIMBO JURÍDICO: LA SITUACIÓN DE REFUGIADOS EN COLOMBIA
}

\author{
SOFía CABARCAS MACIÁ
}

Universidad de los Andes

Facultad de Derecho

Revista de Derecho Público N. ${ }^{\circ} 29$

Julio - Diciembre de 2012. ISSN 1909-7778 


\title{
Cómo escapar el limbo jurídico: la situación de refugiados en Colombia
}

\author{
Sofía Cabarcas Maciá*
}

\section{RESUMEN}

Los refugiados son una comunidad vulnerable que debe gozar de protección internacional a falta de protección por parte de su Estado de origen. Para entrar a gozar de estos derechos los refugiados deben ser reconocidos en su estatus por algún Estado y, por ende, el procedimiento es reglamentado por normas locales. En el caso colombiano, tanto en la norma como en la práctica, hay falencias y vacíos que impiden que los refugiados reciban la protección necesaria, lo cual conlleva en muchos casos la violación de sus derechos fundamentales. En búsqueda de un procedimiento que proteja los derechos humanos se ha realizado un análisis de la jurisprudencia del Tribunal Europeo de Derechos Humanos sobre refugiados, que establece subreglas útiles para el procedimiento en Colombia.

Palabras clave: Refugiado, estatus de refugiado, país receptor, Alto Comisionado de las
Refugees constitute a vulnerable community due to the absence of protection by their home state. Taking into account this lack of protection refugees should benefit from international protection. In order to enjoy of these rights, refugees require the recognition of their refugee status by a state. This procedure is regulated by each country. In Colombia, both in standard and in practice, there are shortcomings and gaps that prevent refugees from receiving the necessary protection that brings as a consequence violation of their fundamental rights. To find a procedure that protects human rights the analysis of the decisions of the European Court of Human Rights about refugees are useful. These decisions provide rules that can be applied to the procedure in Colombia.

KEY WORDS: Refugee, Refugee status, Host country, United Nations High Commissioner for

Abogada de la Universidad de los Andes y estudiante de Antropología de la misma Universidad. Pasante del Programa Misión de Acompañamiento al Proceso de Paz Colombia de la Organización de los Estados Americanos (MAPP-OEA) en el área de Justicia y Paz. Correo: sofiacabarcasmacia@gmail. com. 
Naciones Unidas para los Refugiados (ACNUR), Comisión Asesora del Ministerio de Relaciones Exteriores, fundado temor, persecución, Motivos de la Convención de 1951, riesgo inminente, derecho internacional de los refugiados.
Refugees (UNHCR), Advisory Commission of the Ministry of Foreign Affairs, Well founded fear, Persecution, Reasons of the Geneva Convention of 1951, Real Risk, International Law of Refugees. 


\section{SUMARIO}

Introducción - I. DEFINICIÓN DEL ESTATUS DE REFUGIADO - A. La Convención de 1951 sobre el Estatuto de los Refugiados, su Protocolo de 1967 y la Declaración de Cartagena de 1948 sobre Refugiados - 1. Elementos del Estatuto de los Refugiados - 2. Principio de no devolución - 3. Procedimiento de solicitud de reconocimiento del estatus de refugiado - B. Margen de interpretación en las declaraciones dadas por la persona solicitante del reconocimiento del estatus de refugiado - II. PRÁCTICA EN COLOMBIA EN EL PROCEDIMIENTO DE RECONOCIMIENTO DEL ESTATUS DE REFUGIADO - III. JURISPRUDENCIA INTERNACIONAL SOBRE EL RECONOCIMIENTO DEL ESTATUS DE REFUGIADOS - A. Naturaleza de las decisiones del Tribunal Europeo de Derechos Humanos - B. Relevancia de la jurisprudencia del Tribunal Europeo de Derechos Humanos para el procedimiento de reconocimiento del estatus de refugiado en Colombia - C. Método de análisis de jurisprudencia: subreglas - IV. ANÁLISIS JURISPRUDENCIAL - A. Aplicación del principio de no devolución a la luz del artículo 3 del Convenio para la Protección de los Derechos Humanos y de las Libertades Fundamentales (CEDH) - B. Privación ilegal de la libertad de solicitantes de asilo: retención bajo base legal poco garantizadora de Derechos Humanos, vista como violación al artículo 5 del Convenio para la Protección de los Derechos Humanos y de las Libertades Fundamentales (CEDH) - C. Violación del derecho al respeto de la vida privada y familiar, en los casos de solicitantes de asilo que se les niega asilo a sus familiares, como violación al artículo 8 del Convenio para la Protección de los Derechos Humanos y de las Libertades Fundamentales (CEDH) - D. Violación al derecho a un recurso efectivo, como violación al artículo 13 del Convenio para la Protección de los Derechos Humanos y de las Libertades Fundamentales (CEDH) cuando el solicitante impugna la orden de deportación y no se suspende su ejecución ni se puede discutir el fondo de la decisión - V. CONCLUSIONES - Bibliografía. 


\section{Introducción}

Gatahum Alemo Perefe, etíope de nacimiento, llegó a Bogotá en abril de 2006 sin hablar una palabra de español, tratando de escapar a la persecución que sufría en su país de origen. En su afán por conseguir protección, Gatahum tuvo que pasar por cinco países, recorrido que duró varios años en los cuales fue sometido a tortura a causa de la repetida negación del reconocimiento de su estatus como refugiado. De acuerdo con el Alto Comisionado de las Naciones Unidas para los Refugiados (ACNUR), 11.4 millones de personas en el mundo se encuentran en esta misma situación de desprotección (eltiempo.com, 2008).

Los refugiados son un grupo de personas especialmente vulnerables, puesto que se encuentran en una especie de limbo jurídico: mientras huyen de la persecución de la que son víctimas en su país de origen, esperan recibir la protección jurídica de un Estado extranjero. En respuesta a esta vulnerabilidad surgió el Derecho Internacional de los Refugiados, el cual se creó como desarrollo del artículo 14 de la Declaración Universal de los Derechos Humanos que manifiesta: “1. En caso de persecución, toda persona tiene derecho a buscar asilo, y a disfrutar de él, en cualquier país".

Debido a la vulnerabilidad de estas personas y su carencia de protección estatal, el Derecho Internacional de los Refugiados ha puesto en cabeza de todos los Estados la responsabilidad de brindarles protección. Teniendo en cuenta esta responsabilidad universal, el asilo es el derecho fundamental que tiene toda persona a buscar protección internacional cuando su país de origen no puede, o no quiere, brindársela.

Una vez una persona se encuentra por fuera de su país de origen y formula una solicitud de asilo en el país receptor, se da inicio al proceso de reconocimiento de su estatus, el cual debe estar reglamentado por cada país. En este proceso, en términos generales, se deben revisar unos elementos, tanto objetivos como subjetivos, que constituyen la condición de refugiado. Un ejemplo de un elemento objetivo es que el solicitante esté por fuera de su país de origen. Para comprobar este hecho el funcionario encargado solo debe verificar que el solicitante, en efecto, ya se encuentre en el país receptor. Sin embargo, para comprobar la constitución de los elementos subjetivos se debe tener en cuenta que, en cada caso, el funcionario encargado tiene un margen de interpretación para resolver la solicitud de asilo, ya que su decisión depende de la situación particular de cada solicitante. Un ejemplo de un elemento subjetivo del estatus de refugiado es tener "temor fundado de ser perseguido" debido a que su comprobación implica la apreciación del estado de ánimo del solicitante (ACNUR, 2007, párr. 9). Este margen de interpretación dificulta la creación de reglas generales que limiten el juzgamiento del funcionario e impidan que este profiera una decisión arbitraria.

Colombia no es la excepción. En la práctica, las resoluciones de solicitudes de reconocimiento del estatus de refugiado presentan arbitrariedades. Se sospecha que en muchas ocasiones se toman decisiones políticas que no tienen en cuenta la evaluación de los elementos que forman la condición de refugiado, sino que son ca- 
prichosas, escondiéndose tras la apreciación del funcionario en estos elementos subjetivos. Estas falencias y vacíos han sido identificados por la Procuraduría General de la Nación, que es la única entidad que ha hecho un informe oficial sobre la práctica en el procedimiento de reconocimiento del estatus de refugiado en Colombia y, por ende, será la fuente primaria en este análisis.

Teniendo en cuenta los problemas que surgen en el procedimiento de reconocimiento del estatus de refugiados a nivel nacional, resulta útil tomar subreglas jurisprudenciales que limiten la actividad del funcionario al decidir sobre estos casos. Una buena herramienta es la jurisprudencia del Tribunal Europeo de Derechos Humanos, ya que esta tiene subreglas que delinean criterios para la interpretación de los elementos subjetivos en cada caso.

Este Tribunal produce jurisprudencia basada en las violaciones al Convenio Europeo para la Protección de los Derechos Humanos y de las Libertades Fundamentales (en adelante Convenio Europeo), la cual contiene normas que protegen derechos humanos y obligan a Ios Estados a cumplirlas. Su jurisprudencia es relevante para el caso de refugiados debido a que ha desarrollado una protección a los solicitantes de asilo a través de los artículos 3, 5, 8 y 13 del Convenio Europeo. El artículo 3 protege el derecho a no ser sometido a tratos crueles e inhumanos; el artículo 5 protege el derecho a no ser ilegalmente privado de la libertad; el artículo 8 protege el derecho a la vida privada y en familia y el artículo 13 protege el derecho a un debido proceso.
Teniendo en cuenta lo anterior, las subreglas del Tribunal Europeo resultan de gran utilidad para los casos colombianos de solicitudes de refugio y, por tanto, se debería hacer una traslación de estas al ámbito nacional. Esta importación de subreglas no se puede justificar por medio del Bloque de Constitucionalidad debido a que Colombia no hace parte del Convenio Europeo y, en consecuencia, no obligarían a los funcionarios.

No obstante lo anterior, la jurisprudencia del Tribunal Europeo reviste valor y debería ser aplicada en nuestro ordenamiento interno a nivel nacional. La necesidad de aplicar las subreglas del Tribunal Europeo surge del vacío que hay en la legislación colombiana sobre criterios que guíen al funcionario en la delimitación del margen de interpretación, dentro del procedimiento para el reconocimiento del estatus de refugiado. Además, existe un vacío a nivel regional, ya que en el Sistema Interamericano de Derechos Humanos, del cual hace parte Colombia y el resto de miembros de la Organización de Estados Americanos (OEA), específicamente en la jurisprudencia de la Corte Interamericana de Derechos Humanos, tampoco existen criterios que delimiten la presencia de los elementos que constituyen el estatus de refugiado. Este vacío puede ser suplido por la jurisprudencia de la Corte Europea, ya que esta sí cuenta con un desarrollo de criterios que delimitan el margen de interpretación de los funcionarios, con el propósito principal de proteger los derechos humanos. En consecuencia, el Estado colombiano se vería beneficiado por esta jurisprudencia que, en últimas, reforzaría la protección de 
derechos fundamentales en el Estado social de derecho.

El uso de la jurisprudencia internacional, como un ejercicio de derecho comparado, provee respuestas a interrogantes que surgen a nivel nacional dentro del procedimiento para el reconocimiento del estatus de refugiado. El vaIor hermenéutico de esta jurisprudencia surge a partir de la labor de traslación que se debe hacer al aplicar el derecho internacional a casos domésticos. Karen Knop, en su artículo Here and there: International Law in Domestic Courts, explica que la consecuencia de la traslación del derecho internacional al nivel nacional es el valor de persuasión que resulta útil para la jurisprudencia doméstica. Por lo anterior, "deberíamos explorar el potencial hermenéutico de usar normas internacionales en cortes domésticas para resolver problemas existentes en los juicios nacionales" (KNOP, 2000, p. 504). Debido a que se hace una aplicación acorde en el contexto nacional, la traslación de la jurisprudencia del Tribunal Europeo no sería una nueva forma de imperialismo sino un ejercicio hermenéutico, valioso para el procedimiento del reconocimiento del estatus de refugiado en Colombia.

Teniendo en cuenta el valor hermenéutico de la jurisprudencia del Tribunal Europeo, el presente proyecto pretende analizar esta jurisprudencia internacional sobre el procedimiento de reconocimiento del estatus de refugiado, para identificar las subreglas aplicables a dicho procedimiento en Colombia, en busca de una mayor protección de los derechos humanos de esta población vulnerable.
Para lograr este cometido, en primer lugar se hará un breve recuento de los instrumentos internacionales que vinculan a Colombia y las implicaciones que estos han tenido en la definición del estatus de refugiado y el procedimiento. Luego se explicará el procedimiento en Colombia y se analizarán los vacíos y falencias que tiene. Una vez identificados los problemas a solucionar, se realizará un análisis de la jurisprudencia del Tribunal Europeo que resuelva los errores planteados a partir de las subreglas identificadas. Por último, se reafirmará la utilidad de las subreglas para el procedimiento en Colombia y se explicará cómo este valor hermenéutico apoyaría el proceso de sensibilización de funcionarios sobre la universalidad de los derechos humanos y su protección material.

\section{DEFINICIÓN DEL ESTATUS DE REFUGIADO}

\section{A. La Convención de 1951 sobre el Estatuto de los Refugiados, su Protocolo de 1967 y la Declaración de Cartagena de 1984 sobre Refugiados}

\section{Elementos del estatuto de los refugiados}

La Convención sobre el Estatuto de los Refugiados $^{1}$, principal fuente en el derecho internacional sobre refugiados (DIR), obliga al Estado colombiano al cumplimiento de sus disposiciones en el procedimiento de reconocimiento del esta-

Adoptada el 28 de julio de 1951. Entró en vigor el 22 de abril de 1954 Colombia ratificó esta convención por medio de la Ley 35 de 1961. 
tus de refugiado. Esta Convención define el término "refugiado" como una persona que tiene fundados temores de ser perseguida por una o más de las siguientes cinco razones (conocidas también como los “motivos de la Convención”): 1. Raza, 2. Religión, 3. Nacionalidad, 4. Pertenencia a un determinado grupo social, 5. Opinión política (ACNUR, 2006, p. 20).

Posteriormente, el estatus de refugiado fue ampliado en el ámbito temporal por el Protocolo de 1967, dando la posibilidad de ser refugiado a todas aquellas personas que cumplan los requisitos, prescindiendo de dónde se encuentren y cuándo adquirieron dicha condición (Protocolo, 1967, artículo I). Este cambio se hizo necesario porque la Convención de 1951 había sido expedida pensando en los refugiados de la Segunda Guerra Mundial, anteriores a la expedición del Estatuto, pero las nuevas circunstancias hacían ver que había una diversidad de refugiados que también requerían protección internacional. ${ }^{2}$ Este Protocolo es vinculante para Colombia, que lo ratificó por medio de la Ley 65 de 1979.

En el ámbito regional americano, a estos instrumentos se suma la Declaración de Cartagena sobre Refugiados, firmada el 22 de noviembre de 1984, la cual amplía el concepto de refugiado. La definición de este instrumento, además de contener los elementos de la Convención de

2 "Cada vez era más evidente que la cuestión de los refugiados no era un fenómeno temporal de la posguerra. Las nuevas crisis estaban generando nuevos flujos de refugiados, como había sucedido tras la toma del poder de los comunistas en varios países, desde Checoslovaquia hasta China. Al mismo tiempo, el Telón de Acero entre la Europa oriental y la occidental limitaba la circulación entre ambos bloques". Ver en: ACNUR. (2000). La situación de los refugiados en el mundo 2000. Cincuenta años de acción humanitaria. Icaria editorial, Ausias Marc, Barcelona.
1951 y el Protocolo de 1967, considera también como refugiados "a las personas que han huido de sus países porque su vida, seguridad o libertad han sido amenazadas por la violencia generalizada, la agresión extranjera, los conflictos internos, la violación masiva de los derechos humanos $u$ otras circunstancias que hayan perturbado gravemente el orden público" (Declaración de Cartagena, 1984, Conclusión Tercera). Debido a que la Declaración es un instrumento de soft law, no es vinculante; sin embargo fue firmada por Colombia que, de esta forma, se comprometió a usar su contenido, aunque este no sea exigible por vía judicial. Así, la Declaración debe ser usada como pauta interpretativa en el procedimiento del reconocimiento del estatus de refugiado.

De estos tres desarrollos a nivel internacional y regional del derecho de refugiados, se concluye que los elementos del estatus de refugiado son: 1) Estar por fuera del país de origen; 2) tener un fundado temor; 3) de persecución; 4) por algunos de los cinco motivos enunciados en la Convención de 1951; y 5) no tener segunda nacionalidad donde no sea perseguido y, a la vez, no tener protección por parte del Estado donde sí es perseguido.

\section{Principio de no devolución}

Una vez determinados los elementos básicos que deben reunirse en la definición de refugiado es necesario analizar un elemento adicional. Se trata del principio de no devolución o non refoulement. Este principio es el pilar básico del DIR, pues impone a los Estados la obligación de acoger al interior de sus fronteras a la per- 
sona que reúne las condiciones para ser considerada refugiada y otorgarle de esta manera la protección que su país de origen le niega. El principio se estableció desde los inicios del Derecho Internacional de Derechos Humanos, donde se dio el Derecho Internacional de los Refugiados como un desarrollo del artículo 14 de la Declaración Universal de Derechos Humanos de $1948^{3}$. Posteriormente, el artículo 33 de la Convención de 1951 materializó este principio y lo volvió obligatorio, estableciendo que "ningún Estado Contratante podrá, por expulsión o devolución, poner, en modo alguno, a un refugiado en las fronteras de los territorios donde su vida o su libertad peligre por causa de su raza, religión, nacionalidad, pertenencia a determinado grupo social, o de sus opiniones políticas". Este imperativo es obligatorio y, por ende, el non refoulement es una excepción a la soberanía de un Estado en su ejercicio del control migratorio.

Aunque el principio de non refoulement es el pilar básico del DIR, el artículo 33 de la Convención de 1951 impone una excepción a la aplicación de este. La excepción consiste en que los Estados receptores, para no aplicar el principio, podrán alegar que el solicitante representa un peligro para el orden público. Es así como la Convención supone la ponderación entre el derecho a no ser sometido a torturas y el fin de un Estado de proteger su soberanía y seguridad.

En caso de incumplir la obligación de no devolver, el Estado sería responsable internacio-

3 Artículo 14. 1. En caso de persecución, toda persona tiene derecho a buscar asilo, y a disfrutar de él, en cualquier país. 2. Este derecho no podrá se invocado contra una acción judicial realmente originada por delitos comunes o por actos opuestos a los propósitos y principios de las Naciones Unidas. nalmente, ya que como receptor de refugiados tiene el deber de analizar la situación de manera cuidadosa para evitar que sus decisiones causen mayores violaciones de los derechos de esta población vulnerable. En consecuencia, el Principio de no devolución es la prohibición más importante del DIR y, por consiguiente, se designa como el pilar esencial. Sin este no habría límite a la soberanía de los Estados y nunca tendrían que dar protección a refugiados.

\section{Procedimiento de solicitud de reconoci- miento del estatus de refugiado}

El procedimiento de reconocimiento del estatus de refugiado es declarativo mas no constitutivo ya que, según la Convención de 1951, una persona es refugiada desde el momento en que reúne los requisitos enunciados en la definición y esto ocurre antes de que sea reconocido formalmente por un Estado (ACNUR, 2005, párr. 7). No obstante, este carácter declarativo no se ve reflejado en la práctica. Para tener acceso a los derechos que acarrea la condición de refugiado es necesario que dicho estatus sea reconocido por algún Estado. Sin este reconocimiento la persona queda desprotegida, por lo que la constitución de los elementos con anterioridad a la declaración formal parecería no tener ninguna consecuencia. Es así como, en el momento en que un Estado no le otorga el estatus a un refugiado, este queda desprotegido y en búsqueda de otro país que le pueda garantizar su protección. En consecuencia, el reconocimiento es un requisito necesario para que el refugiado pueda gozar de sus derechos. 
En el procedimiento de asilo se analizan los elementos de la condición de refugiado a partir de las declaraciones dadas por el solicitante, y cada Estado tiene su propio reglamento sobre este procedimiento. En el caso de Colombia, la Constitución Política protege el asilo en su artículo 36, situado en el capítulo I del Título II sobre los derechos fundamentales. Esto implica la superioridad jerárquica del asilo frente a otros derechos que no gozan del rango de derecho fundamental. Además, el derecho de asilo es reconocido por la Corte Constitucional como una garantía que tiene toda persona ante el ordenamiento jurídico internacional (C. Const., 1996, Resumen Ejecutivo), reiterando la importancia de este derecho dentro del Estado social de derecho.

Aunque la Constitución enuncia el derecho al asilo, el procedimiento para el reconocimiento del estatus se regula por medio del Decreto 4503 de noviembre 19 del 2009. El Decreto repite en su artículo primero los elementos de la Convención de 1951 sobre el Estatuto de los Refugiados, por lo cual el procedimiento implica el análisis de los elementos subjetivos y objetivos mencionados anteriormente. La entidad ante la cual se debe presentar la solicitud para el reconocimiento del estatus de refugiado es el Despacho del Viceministro de Asuntos Multilaterales del Ministerio de Relaciones Exteriores. El solicitante tiene un término de 60 días, contados a partir del día de entrada al país, para presentar la solicitud. La Comisión Asesora del Ministerio de Relaciones Exteriores ${ }^{4}$ analiza el

4 La Comisión Asesora fue catalogada como cuerpo consultivo del Presidente de la República por el artículo 225 de la Constitución Política de Colombia. Además este artículo ordenó que la composición de dicho órgano fuera determinado por la ley. Siguiendo este mandato, caso y emite un concepto para el Ministro, sobre la viabilidad de la solicitud. El producto de este procedimiento es una decisión adoptada por el Ministro en una resolución que puede ser impugnada por medio del recurso de reposición.

En este procedimiento el Ministro debe interpretar los elementos subjetivos en cada caso, es decir, debe valorar las declaraciones del solicitante en su escrito de solicitud de reconocimiento del estatus de refugiado. La interpretación de las declaraciones es muy importante y se debe hacer de manera justa para asegurar que se dé la protección que el ordenamiento internacional exige a los países con respecto a esta población tan vulnerable.

\section{B. Margen de interpretación en las de- claraciones dadas por la persona solicitante del reconocimiento del estatus de refugiado}

Teniendo en cuenta que el procedimiento de reconocimiento del estatus de refugiado se conforma principalmente por el análisis de las declaraciones de los solicitantes, es necesario que todos los requisitos enunciados en la Con-

\footnotetext{
el Congreso de la República expidió la Ley 68 de 1993 la cual fue modificada por la Ley 955 de 2005. En esta se indica que la Comisión debe estar compuesta por doce miembros elegidos de los integrantes de las Comisiones Segundas Constitucionales así: tres por el Senado pleno con sus respectivos suplentes y tres por el pleno de la Cámara de Representantes con sus respectivos suplentes. Los miembros que representen al Congreso tendrán el mismo período de las Cámaras que les hayan elegido. Los designados por el Presidente de la República tendrán el mismo período de este. Unos y otros continuarán en el ejercicio de sus funciones mientras no sean reemplazados. Dentro de las funciones de este órgano está tratar el tema de Política Internacional de Colombia y dentro de este tema se incluye el reconocimiento del estatus de refugiado. Esta Comisión tiene reuniones ordinarias e informativas. Las informativas pueden ser convocadas por el Ministro de Relaciones Exteriores y en estas se generan las recomendaciones para el Ministro sobre los casos de solicitudes de refugio. El Ministerio de Relaciones Exteriores es la Secretaría Técnica de la Comisión.
} 
vención sobre el Estatuto de los Refugiados estén presentes en cada caso. Como se dijo anteriormente, varios de estos elementos dejan un amplio margen de interpretación ya que su contenido no ha sido fijado por instrumentos internacionales ni por normas domésticas. Dichos elementos son: 1) Estar por fuera del país de origen, 2) tener un fundado temor; 3) de persecución; 4) por algunos de los cinco motivos enunciados en la Convención de 1951 y 5) sin tener segunda nacionalidad donde no lo persigan y no reciba protección por parte del país donde es perseguido (ACNUR, 2007, párr. 3).

Para determinar la existencia del primer criterio se debe comprobar que la persona no tenga una segunda nacionalidad en donde no esté siendo perseguido, capaz de darle protección. Este elemento es el único que no tiene un margen de interpretación.

Una vez el solicitante se encuentra por fuera de su país de origen, se debe constituir el tercer elemento: la persecución, que es el que distingue el refugio como forma de asilo del resto de las formas de protección internacional acordadas bajo el Sistema Interamericano (ACNUR, 2007, párr. 1). El término persecución no ha sido definido en ningún tratado internacional pero el Alto Comisionado de las Naciones Unidas para los Refugiados (ACNUR) ${ }^{5}$ lo ha definido

5 El mandato principal del ACNUR es garantizar la protección internacional de aproximadamente 36.4 millones de personas desarraigadas en el mundo. La protección internacional de los refugiados comienza por garantizar su admisión en un país de asilo seguro, el otorgamiento del asilo y asegurar el respeto de sus derechos humanos fundamentales, incluyendo el derecho a no ser regresado forzosamente a un país donde su seguridad o su supervivencia estén amenazadas (principio de no devolución o non refoulement). Termina solo con la obtención de una solución duradera. El ACNUR trabaja con los gobiernos para ayudarlos a enfrentar estos desafíos de una forma efectiva y coherente. El Plan de como "un daño intencional e injusto a una persona debido a determinadas características que la misma posee. Este daño, se traduce siempre en una determinada violación a los derechos humanos de la víctima" (ACNUR, 2007, párr. 14). Por lo anterior, el funcionario deberá evaluar la gravedad del daño sufrido o temido para determinar si existe una persecución real o no. El ACNUR recomienda que los funcionarios se remitan a instrumentos internacionales de derechos humanos para establecer la gravedad del daño que se sufrió o se podría sufrir "preguntándose ¿Qué derechos han sido vulnerados y en qué medida?" (ACNUR, 2007, párr. 15).

Además del carácter subjetivo de la persecución, el funcionario debe comprobar que la situación del país de origen sea peligrosa para el solicitante. Esto implica que la determinación de la condición de refugiado como persona que ha sido perseguida o teme serlo, debe tener en cuenta, además de las condiciones personales, un sustento razonable y lógico de la persecución sufrida en el país específico de cada solicitante. Para esto el funcionario se debe informar sobre el contexto de dicho país y una forma fácil de hacerlo es pidiendo a oficinas del ACNUR de ese Estado que remitan información útil sobre la posibilidad de persecuciones a personas como el solicitante.

El segundo elemento, "fundados temores", implica que se tiene un temor como consecuencia de la persecución. "El término "bien fundado te-

\footnotetext{
Acción de los 10 Puntos del acnur sobre los movimientos migratorios mixtos identifica áreas estratégicas en las cuales tomar acción para responder a las migraciones mixtas en los países de origen, tránsito y destino. Ver en: ACNUR. ¿Qué hace? Recuperado el 30 de mayo de 2012 del url: http://www.acnur.org/t3/que-hace/asilo-y-migracion/
} 
mor' contiene un elemento subjetivo y uno objetivo, y al determinar la situación de un refugiado, quienes toman la decisión deben considerar ambos" (ACNUR, 2001, p. 4). El elemento subjetivo consiste en el temor, que puede ser medido a partir del caso específico, es decir, de las características personales del solicitante. El elemento objetivo se puede medir informándose sobre la situación del país de origen. El análisis debe resultar en que el fundado temor sea "razonable" para que la persona no pueda volver al país de origen.

Además de la existencia de este temor, el funcionario debe comprobar que la persecución obedezca a uno de los cinco motivos establecidos en el artículo 1 A (2) de la Convención. Esta comprobación, como sucede con otros elementos, también implica un margen de interpretación. Por ejemplo, definir si el solicitante pertenece a un grupo social puede resultar muy difícil ya que los grupos pueden cambiar su conformación en el tiempo. Además de esta dificultad, la relación causal entre el fundado temor y el motivo de persecución, en muchos casos, no es clara y por esto es necesario tener jurisprudencia que aclare cómo determinar la causalidad.

Por recomendaciones del ACNUR, en el análisis de estos elementos se debe tener una visión comprensiva, es decir, global o completa, de los motivos que han Ilevado al solicitante de la condición de refugiado a abandonar su país de origen o residencia habitual. "Es claro que caer en un análisis muy puntilloso de los componentes de la definición puede distraer la atención del propósito central que se pretende alcanzar, es decir, el brindar protección internacional a aque- llas personas necesitadas de la misma" (ACNUR, 2005, p. 4).

Teniendo en cuenta los elementos que constituyen el estatus de refugiado y su margen de interpretación ahora debemos indagar cómo se aplica el procedimiento en Colombia.

\section{PRÁCTICA EN COLOMBIA EN EL PROCEDIMIENTO DE RECONOCIMIENTO DEL ESTATUS DE REFUGIADO}

Esta sección va a mostrar los fallos de los funcionarios al aplicar el procedimiento para el reconocimiento del estatus de refugiado, los cuales son producto, entre otras cosas, de la ausencia de reglas y criterios de interpretación claros, unificados y acordes con el principio pro homine que debe regir la aplicación de las normas de derechos humanos. Estos vacíos y falencias en el procedimiento han sido recopilados por el Grupo de Desplazamiento Forzado y Refugio de la Delegada Preventiva en materia de Derechos Humanos y Asuntos Étnicos de la Procuraduría General de la Nación. Esta entidad realizó unas visitas programadas a nivel nacional para analizar la implementación del Decreto 4503 de 2009. En ellas se hallaron "graves falencias de las autoridades competentes en cuanto a la atención de ciudadanos extranjeros que ingresan a territorio nacional en búsqueda de protección internacional." (Procuraduría General de la Nación, 2011, p. 37).

Un primer error que se encontró fue que Colombia, por lo general, es concebida como país de 
origen y no de destino de refugiados, debido a que "el conflicto armado no solo ha generado el desplazamiento forzado interno de personas que buscan lugares seguros dentro del territorio nacional, sino también la salida forzosa del mismo" (Procuraduría General de la Nación, 2011, p. 10). Sin embargo, Colombia también es un país receptor de refugiados procedentes de múltiples países y, por ende, tiene reglamentación sobre el procedimiento para la determinación de la condición de refugiado a nivel interno (Procuraduría General de la Nación, 2011, p. 10).

A pesar de la gran cantidad de refugiados que llegan al país, esta población no parece ser reconocida. En las fronteras colombianas no hay una diferenciación clara entre migrantes económicos, tráfico de personas y refugiados. Parece haber una falta de conocimiento sobre los derechos especiales de esta población y, por consiguiente, las autoridades migratorias, que en Colombia conforman el Departamento Administrativo de Seguridad (DAS) ${ }^{6}$, ordenan la deportación de la mayoría como un método de filtro (Procuraduría General de la Nación, 2011, p. 45). Es así como, ante los flujos mixtos, en los cuales hay migrantes económicos, tráfico de personas, migrantes ilegales y refugiados, el DAs no tiene en cuenta la existencia de refugiados y, en vez de dar un trato especial a esta población, deporta a todo aquel que haya entrado de manera irregular al país. Lo anterior se debe a que la autoridad migratoria cree que el objetivo de estos es engañarla

6 Esta entidad está en proceso de supresión a partir de la expedición del Decreto Ley 4057 del 31 de octubre de 2011. Una vez concluya este proceso las funciones de migración quedarán a cargo de la Unidad Administrativa Especial Migración Colombia, del Ministerio de Relaciones Exteriores; de la Fiscalía General de la Nación; y de la Unidad Nacional de Protección, adscrita al Ministerio del Interior. pues se trata de "migrantes ilegales que vienen "adoctrinados" por los traficantes para que manifiesten que son solicitantes de asilo o que se encuentran enfermos" (Procuraduría General de la Nación, 2011, p. 46).

Las declaraciones del director del DAS a la Procuraduría explican el comportamiento de los funcionarios de esta agencia estatal. En su concepto, Colombia se ha convertido en un lugar de tránsito necesario para continuar hacia los Estados Unidos, debido a la facilidad de acceso a las rutas por Centro América. En consecuencia, la autoridad migratoria, para combatir esta realidad, apela a los procedimientos de inadmisión, deportación y expulsión con las personas que se encuentren ilegalmente en el país. Esta concepción sobre la forma de combatir el tráfico de personas demuestra desinformación y falta de capacitación sobre el manejo de los refugiados, lo cual los deja en una situación de desprotección desde la primera fase de su llegada al país.

Si el refugiado no es expulsado inmediatamente y accede a información sobre el procedimiento de reconocimiento del estatus de refugiado, en la mayoría de los casos será enviado por la autoridad migratoria a la oficina del ACNUR más cercana al sitio por donde ingresó al país. Al tener conocimiento sobre la existencia de un refugiado en el territorio colombiano, ACNUR lo remite a su Agencia implementadora en Colombia, el Secretariado Nacional de Pastoral Social (SNPS) ${ }^{7}$.

\footnotetext{
$7 \quad$ Esta Agencia se encarga de cumplir el mandato del ACNUR de apoyar a los refugiados en el procedimiento para el reconocimiento de su estatus. Este apoyo implica ayudar a los refugiados a redactar las solicitudes, hacerle seguimiento a los casos hasta que se les niegue o reconozca el estatus de refugiado y prestarles asistencia humanitaria, la cual consiste en darles posada en albergues cuando no cuenten con
} 
La asistencia que presta el SNPS es subsidiada por ACNUR, como parte del cumplimiento de su mandato de apoyar a los refugiados y velar por la protección de sus derechos. El agente civil suple al Estado en esta protección, a pesar de que en Colombia los refugiados son sujeto de todos los derechos fundamentales, que incluyen acceder a una vivienda digna.

La solicitud para el reconocimiento del estatus de refugiado debe ser presentada antes de los 60 días de haber ingresado al país (Decreto 4503 de 2009, art. 5). A raíz de esta solicitud se expide un salvoconducto que le da derecho al refugiado a permanecer tres meses en territorio colombiano (Decreto 4503 de 2009, art. 8). Dicho salvoconducto es renovable por otros seis meses cuantas veces sea necesario, mientras continúe el procedimiento. En esta etapa entre presentar la solicitud y esperar la resolución del Ministerio, también los funcionarios de la Procuraduría encontraron varias falencias. En primer lugar, el tiempo promedio del trámite de una solicitud en nuestro país es de seis a siete meses de acuerdo con el Decreto, pero en la práctica toma de nueve meses hasta dos años (Procuraduría General de la Nación, 2011, p. 38). Esta demora podría estar relacionada con el margen de interpretación que tienen los funcionarios para determinar la existencia de los elementos constitutivos del estatus de refugiado, quienes podrían estar usándolo para dilatar el proceso y negar la protección que se debe proveer.

En el procedimiento a cargo de la Comisión Asesora del Ministerio de Relaciones Exteriores, no

los medios económicos para conseguir una vivienda digna mientras se resuelve su solicitud. es obligatorio para los funcionarios realizar entrevistas a los solicitantes luego que presentan su solicitud por escrito (Decreto 4503 de 2009, art. 9), lo cual implica que no se les da el espacio necesario para declarar su situación ante la autoridad competente, de una manera libre de presiones externas. El SNPS ha afirmado que en los casos en que la Comisión Asesora -en ejercicio de la facultad otorgada por el artículo 9 del Decreto 4503 de 2009- decide no hacer entrevista, si determina que la solicitud es evidentemente infundada, se remiten al proceso acelerado ${ }^{8}$. Este proceso consiste en remitir a los solicitantes cuyo caso es considerado como manifiestamente infundado o claramente abusivo, a un procedimiento en el que el análisis legal no es completo como en el proceso ordinario, simplemente se hace una breve descripción de las razones por las cuales se niega la solicitud y, en consecuencia, la mayoría de las veces, se resuelven las solicitudes de manera negativa. La falta de entrevista antes de remitir el caso a proceso acelerado constituye una violación del derecho fundamental al debido proceso (Const. Política 1991, art. 29), puesto que no se le está permitiendo al solicitante ejercer su derecho de contradicción.

En esta fase del procedimiento, el informe de la Procuraduría reporta otra falencia: la falta de personal en la Comisión Asesora. Una vez se presenta la solicitud y se expide el salvoconduc-

8

Artículo 11. Cuando se identifique un caso, durante la recepción de la solicitud o una vez iniciado el trámite de reconocimiento de la condición de refugiado, que pueda ser considerado como manifiestamente infundado o claramente abusivo, el tratamiento del caso quedará sujeto a lo previsto en el artículo 12 del presente decreto, sobre el procedimiento acelerado, establecido conforme a las directrices estipuladas por el Comité Ejecutivo de la Oficina del Alto Comisionado de las Naciones Unidas para los Refugiados. 
to, es labor de la Comisión Asesora llevar a cabo el procedimiento y dar unas recomendaciones al Ministro para que expida la resolución que resuelve la solicitud, por tanto la falta de personal en esta Comisión implica que "no se están brindando las garantías suficientes en términos de eficiencia (esto es, el tiempo que toma el trámite de cada solicitud) y en términos de eficacia (evidenciada en la ausencia de traductores en el trámite)." (Procuraduría General de la Nación, 2011, p. 38). Esta demora conlleva que los solicitantes no puedan trabajar y vivan en albergues en condiciones poco higiénicas durante este tiempo.

Además de esta demora, los miembros de la Comisión Asesora también caen en errores al momento de determinar la existencia de los elementos de inclusión en la categoría de refugiado:

Es frecuente encontrar que las autoridades competentes incurran en presunciones de falsedad y discriminen a las personas provenientes de determinados países, como por ejemplo Afganistán o Irak, al relacionarlos indefectiblemente con grupos extremistas o terroristas. Así también, pareciera asumirse que todos los solicitantes de asilo corresponden a migrantes económicos que están utilizando a Colombia como país de tránsito para llegar a otros destinos, principalmente a los Estados Unidos (Procuraduría General de la Nación, 2011, p. 39).

Las presunciones y discriminaciones impiden que se dé la protección requerida a nivel internacional al refugiado. El margen de interpretación de estos elementos es usado para disfrazar una discriminación en contra de esta población vulnerable, violando su derecho fundamental a la igualdad.

La resolución que resuelve la solicitud y que es necesaria para alcanzar una materialización de la protección, en muchos casos es negativa?. Cuando esto sucede, el refugiado no cuenta con un recurso administrativo para apelar la decisión, solo puede pedir la reposición (Decreto 4503 de 2009, Art. 16) y esta no es un recurso idóneo debido a que requiere que la misma autoridad, es decir, el ministro de Relaciones Exteriores, reconsidere su decisión, que la mayoría de veces no cambia.

Ante la falta de un recurso administrativo apropiado, los solicitantes de asilo acuden a la tutela. La tutela está diseñada para proteger derechos fundamentales en casos en que no haya otra vía adecuada para hacerlo, es decir, su naturaleza es subsidiaria. Los refugiados que reciben respuestas negativas a sus solicitudes, en las tutelas alegan que se les ha violado el derecho al debido proceso y a la vida, entre otros, en búsqueda de una segunda oportunidad en el procedimiento frente al Ministerio. La sentencia que resuelve una tutela no puede reconocer el estatus de refugiado ni obligar al Ministerio a

9 "En reunión sostenida con la Secretaría Técnica de la Comisión Asesora para la Determinación de la Condición de Refugiado, le fue informado al Grupo de Desplazamiento Forzado y Refugio que el 96\% de las solicitudes de asilo llegan a través de las oficinas del ACNUR o de la Pastoral Social, y que dicha Secretaría no cuenta con estadísticas relacionadas con las solicitudes que son inadmitidas para la iniciación del trámite, lo cual por sí mismo evidencia una falencia frente a los sistemas de gestión y control de la entidad, puesto que ésta es una clara actividad de índole misional." Ver: Procuraduría General de la Nación. (2011). Informe en materia de asilo y recomendaciones para la creación de la línea de intervención de la Procuraduría General de la Nación en esta materia. Procuraduría delegada para la prevención en materia de derechos humanos y asuntos étnicos. Grupo de desplazamiento forzado y refugio. Bogotá (p. 39 y 40). 
que lo haga. Solo puede declarar si hubo o no una violación al debido proceso y, de haberla, se debe iniciar nuevamente el procedimiento para el reconocimiento de la condición de refugiado.

\section{JURISPRUDENCIA INTERNACIONAL SOBRE EL RECONOCIMIENTO DEL ESTATUS DE REFUGIADOS}

La gran cantidad de vacíos y falencias identificadas por la Procuraduría deben servir de alarma para las autoridades colombianas frente a la falta de protección que están recibiendo los refugiados en Colombia. La falta de protección indica que se necesitan criterios que sirvan de referencia para que las resoluciones y decisiones tomadas sean acordes con la protección de los derechos humanos que requiere el Derecho Internacional de los Refugiados. Estos criterios se pueden encontrar en la Jurisprudencia del Tribunal Europeo de Derechos Humanos, debido a que el fin primordial de este organismo es proteger los derechos fundamentales de las personas.

\section{A. Naturaleza de las decisiones del Tribunal Europeo de Derechos Humanos}

El Tribunal Europeo hace parte del sistema regional Ilamado Sistema Europeo de Derechos Humanos. Este organismo fue creado por el Convenio para la Protección de los Derechos Humanos y de las Libertades Fundamentales, que fue adoptado por el Consejo de Europa en 1950 y entró en vigor en 1953. En el artículo 19 de la Convención se creó el Tribunal Europeo con el fin de asegurar el cumplimiento de la Convención y sus protocolos. Además del Tribunal, existía una Comisión encargada de remitir los asuntos presentados a la Corte. El 31 de octubre de 1998, el Protocolo 11 de la Convención cambió el régimen mixto de Comisión-Corte y permitió que los particulares acudieran directamente ante el Tribunal, suprimiendo la Comisión.

El Tribunal funciona como una organización intergubernamental que toma decisiones que definen la responsabilidad a los países miembros. Los solicitantes ante la Corte deben agotar recursos internos previamente y demostrar que sus derechos no han sido protegidos efectivamente a nivel nacional. Una vez se presenta la demanda ante el Tribunal, este evalúa la admisibilidad. Después de ser admitido el caso se toma una decisión sobre si hubo o no violación de la Convención (Convenio Europeo de Derechos Humanos, 1950, art. 35).

El procedimiento del Tribunal evidencia que este puede juzgar situaciones en las que los refugiados o solicitantes de refugio han sido vulnerados en sus derechos fundamentales contenidos en el Convenio. Este juzgamiento implica que el Tribunal puede decidir si la Corte nacional que se pronunció sobre la solicitud de refugio violó derechos humanos reconocidos por la Convención Europea de Derechos Humanos.

\section{B. Relevancia de la jurisprudencia del Tribunal Europeo de Derechos Humanos para el procedimiento de reconocimien- to del estatus de refugiado en Colombia}

Teniendo en cuenta las falencias del decreto colombiano que reglamenta el procedimiento del 
reconocimiento del estatus de refugiado y los errores que se cometen en la práctica, resulta necesario ver cómo se podrían solucionar estos problemas. La jurisprudencia del Tribunal Europeo de Derechos Humanos, que trata el tema específico de violaciones a derechos fundamentales en el procedimiento de reconocimiento del estatus del refugiado, resulta relevante para el caso colombiano. Al identificar las violaciones que se pueden cometer en este proceso, la Corte está identificando límites en esta práctica y establece los casos en que el estatus debe ser reconocido para no caer en transgresiones de derechos humanos.

Es por esto que al extraer subreglas que indiquen los límites y exigencias del procedimiento de reconocimiento del estatus de refugiado, se podrá dar claridad sobre cómo resolver los errores en la práctica colombiana.

\section{Método de análisis de jurisprudencia: subreglas}

Debido a que la materia prima de este trabajo son las decisiones del Tribunal Europeo de Derechos Humanos, resulta necesario evidenciar el método que se usará para analizar estos textos. Dicho método será el de subreglas, propuesto por Diego López en su libro Derecho de los jueces. El método consiste en extraer de la sentencia la regla que se aplicó al caso, la cual está conformada por un supuesto de hecho y una consecuencia jurídica. Estas subreglas son aplicables a otros casos y así se forman las líneas jurisprudenciales que constituyen un precedente aplicable a un nuevo caso. En consecuencia, lo más importante es identificar la situación específica que dio lugar a la decisión tomada por la Corte y comparar estos hechos con casos nacionales. Una vez se encuentra una semejanza entre los casos, es posible aplicar la subregla cuya estructura es: Si pasa A debe ser B, debido a C.

A continuación se aplicará esta estructura a las decisiones del Tribunal Europeo de Derechos Humanos, en busca de aclarar las decisiones tomadas por la Corte y analizar su aplicabilidad a casos en Colombia.

\section{ANÁLISIS JURISPRUDENCIAL}

Como se mencionó en la introducción, este proyecto se propone hacer una revisión de los fallos del Tribunal Europeo de Derechos Humanos que ayuden al desarrollo de los elementos de la condición de refugiado, en Colombia. Dichos fallos establecen subreglas que delimitan cómo se debe manejar el margen de interpretación que dejan los elementos de inclusión del estatus de refugiado, para evitar violaciones a los derechos fundamentales. La jurisprudencia que se analizará refuerza la protección de derechos consagrados en el Convenio Europeo de Derechos Humanos que, en últimas, permite proteger los derechos de los refugiados, consagrados en los instrumentos del derecho internacional de los refugiados. Esta protección es un ejemplo para Colombia y debido al valor hermenéutico de la jurisprudencia internacional es necesario tener en cuenta estas subreglas. 


\section{A. Aplicación del principio de no devolu- ción a la luz del artículo 3 del Convenio para la Protección de los Derechos Hu- manos y de las Libertades Fundamenta- les (CEDH)}

La aplicación del principio de no devolución (non refoulement) es de gran importancia para proteger efectivamente los derechos de los refugiados. El Tribunal Europeo ha consolidado una jurisprudencia homogénea, que evidencia una clara y más amplia protección del derecho a no ser devuelto, en caso de haber un riesgo de sufrir una tortura a la luz del artículo 3 del Convenio Europeo. Es más amplia la protección puesto que la prohibición de torturas en el Sistema Europeo es absoluta, en cambio el principio de no devolución en el derecho internacional de los refugiados tiene excepciones.

Esta línea jurisprudencial resulta relevante para los casos colombianos en que las personas que aspiran ser reconocidas como refugiados no son bien informadas de sus derechos, y contra las cuales se dicta orden de expulsión por parte del DAs, sin permitirles acceder de manera adecuada al procedimiento, violando su derecho al debido proceso y poniendo en riesgo su integridad física y moral.

Un ejemplo de este error es el caso de Reza Pirhadi contra el Ministerio de Relaciones Exteriores y el Departamento Administrativo de Seguridad DAS. En este, el iraní Reza Pirhadi ingresó al país buscando refugio pero las autoridades lo procesaron por el delito de falsedad material de particular en documento público y como resultado se ordenó su expulsión, sin considerar que la devolución de este sujeto a Irán conllevaría su muerte ${ }^{10}$. La persona sí accedió al procedimiento para el reconocimiento del estatus de refugiado pero fue informado de la existencia de este procedimiento mucho después de su entrada al país. Además, una vez presentó la solicitud el proceso demoró un año y se resolvió negativamente sin mayor motivación. El señor Pirhadi tuvo que interponer acciones de tutela para que su orden de deportación no se hiciera efectiva (C. Const., 2003).

La Corte Constitucional resolvió que el derecho del señor Pirhadi al debido proceso había sido vulnerado y, por lo tanto, se debía comenzar otra vez el procedimiento del reconocimiento del estatus de refugiado. La Corte no ordenó que sí se le reconociera el estatus de refugiado, por lo cual no asegura que el tutelante recibirá la protección que requiere. Esto implica que la tutela no es el mecanismo idóneo para proteger los derechos de estas personas, debido a que no tiene poder sobre la decisión sustancial. Solo vela por la protección de los derechos fundamentales de estas personas en el procedimiento pero no puede ordenar reconocerles el estatus para que accedan a los derechos que les corresponde. Este caso muestra que en Colombia el Ministerio no está valorando las demostraciones sumarias de peligro en el país de origen y niega el estatus de refugiado sin mayor

10 Este riesgo fue demostrado por el solicitante al decir: "Tengo temor de regresar a mi país por la situación que vive actualmente y en especial porque creo que miembros del Ministerio de Información del Gobierno y la oficina encargada de los mismos asuntos en el Ejército pueden hacerme daño, afectando mi integridad física, ya que me vinculan a activismo político, lo cual es bastante grave dado (sic) mi vinculación con el Ejército" (C. Const., 2003, p. 15). 
motivación, haciendo necesario que los solicitantes acudan a la tutela, que no es la institución jurídica idónea para proteger sus derechos.

Teniendo en cuenta estos hechos se analizarán las subreglas del Tribunal Europeo y se valorará cómo estas pueden ayudar a resolver estos errores en el procedimiento en Colombia.

\section{Caso Soering c. Reino Unido. (Sentencia de 7 de julio de 1989)}

En esta decisión el Tribunal analizó la situación del señor Jens Soering, nacional de Alemania, quien fue capturado y puesto en prisión en Inglaterra esperando cumplir orden de extradición a Estados Unidos, en donde confrontaba cargos de homicidio. El cargo de homicidio tiene pena de muerte en Estados Unidos y la espera para dicha pena es de mínimo siete años. Tras esto la embajada de Inglaterra en Washington DC pidió que en caso de entregar al señor Soering a Estados Unidos, a este no se le impusiera la pena de muerte debido a que esta había sido abolida en Inglaterra, dando cumplimiento al tratado de extradición.

Mientras sucedían estos trámites se expidió un dictamen psiquiátrico que declaraba que el señor Soering sufría de un trastorno mental y el perito adjudicó los homicidios a esta causa.

Teniendo en cuenta estos hechos, la Corte pasó a revisar las condiciones de un prisionero en el "túnel de la muerte", en la institución carcelaria Mecklenburg de Virginia, y constató que los reos son sometidos a semanas de aislamiento sin luz, a los guardas no se les permite inter- venir en caso de ataques entre reos y además la estancia en el túnel de la muerte dura entre siete y ocho años debido a que hay una práctica de alargar los procesos.

Ante esto el Tribunal concluyó que esperar ocho años antes de la ejecución inminente, bajo condiciones degradantes en el túnel de la muerte, constituye el delito de tortura. El artículo 3 del CEDH prohíbe que se someta a las personas a tratos crueles e inhumanos y cumplir la orden de extradición a Estados Unidos del señor Soering constituiría someterlo a la tortura. Es así como la Corte Europea protegió el principio de no devolución consagrado en el derecho internacional de los refugiados, en caso de peligro de tortura o muerte en el país de origen, a través del artículo 3 de su Convenio.

La subregla que estableció el Tribunal en esta providencia fue que cuando una decisión de extradición pueda afectar el ejercicio de un derecho protegido por el Convenio, podrían resultar exigibles al Estado Parte ciertas obligaciones tendientes a prevenir la vulneración de la disposición en cuestión. Esta subregla ordena que el Estado tome acciones positivas para que una orden de extradición no afecte derechos fundamentales de los solicitantes de asilo. Al hacer esto el Estado debe dar prevalencia al principio de no devolución sobre cumplimiento de extradición, es decir, debe ceder su ejercicio soberano de control migratorio para proteger los derechos de estas personas. 


\section{Caso Cruz Varas y otros c. Suecia. (Sentencia de 20 de marzo de 1991)}

Héctor Cruz Varas, su esposa y su hijo, de nacionalidad chilena, presentaron solicitud de asilo político en Suecia. El señor Cruz declaró a las autoridades suecas que él pertenecía al partido socialista en Chile y al entrar al régimen el general Pinochet, lo destituyó y fue detenido acusado de participar en política en contra del régimen; pero además aludió que su razón principal para irse de Chile era no poder conservar su casa por su mala situación económica. El gobierno sueco no le reconoció el estatus de refugiado debido a que no tenía suficientes motivos políticos fuertes para constituir la calidad de refugiado. Se expidió orden de expulsión y el señor Cruz apeló. Lo interrogaron nuevamente para que diera más detalles sobre su persecución en Chile. Luego se expidieron dos reportes médicos sobre las secuelas psicológicas que dejaron en el señor Varas las torturas a las que fue sometido en su país. El 6 de octubre de 1989 las autoridades consideraron que no había impedimentos para ejecutar la expulsión y lo deportaron a Chile; su esposa e hijo se escondieron en Suecia.

En esta sentencia la Corte aplicó la subregla del caso Soering, por la cual una decisión de extradición no puede afectar el ejercicio del derecho a no ser sometido a torturas o tratos crueles e inhumanos, protegido por el Convenio. El Estado tiene, entonces, la obligación de tomar acciones tendientes a prevenir la vulneración de la disposición en cuestión, en los casos de expulsión donde hay un riesgo inminente (real risk). Este riesgo es un desarrollo jurisprudencial de la Cor- te. En este caso el Tribunal estableció que para saber si la persona está ante un riesgo real que vaya en contravía del artículo 3 del Convenio, el Tribunal debe analizar las pruebas dadas por el solicitante, que son principalmente sus afirmaciones en la entrevista. El señor Cruz Varas, en este caso, mantuvo silencio durante más de dieciocho meses, desde su primer interrogatorio, sobre las actividades clandestinas que había llevado a cabo en su país y sobre las torturas que le habían infligido las autoridades chilenas. Esto puso en duda su credibilidad y por esto el Tribunal concluyó que no se pudo probar sumariamente la existencia de un riesgo inminente. Hubo contradicciones en las versiones dadas a lo largo de los distintos interrogatorios y esto hizo imposible establecer una coherencia, que probara el riesgo de ser sometido a torturas si era devuelto a Chile (TEDH, 1989, párr. 69 y 73). El Tribunal afirmó que se debía juzgar la credibilidad del solicitante, sin violar su derecho a no ser devuelto al país de origen, de existir un riesgo inminente de ser sometido a tratos crueles o muerte.

\section{Caso Vilvarajah y otros c. Reino Unido. (Sentencia de 30 de octubre de 1991)}

El señor Vilvarajah, nacido en Sri Lanka, perteneciente a la etnia Tamil, fue detenido en varias ocasiones y recibió golpes severos por parte de las fuerzas navales de dicho país. Su familia y él estaban en peligro de muerte y perdieron todas sus pertenencias. El señor Vilvarajah solicitó asilo en el Reino Unido y su solicitud fue negada debido a que se consideró que no tenía un temor fundado razonable de persecución. El 10 
de febrero de 1988 el solicitante fue devuelto a Sri Lanka y sufrió nuevas amenazas por pertenecer al PLOTE (People's Liberation Organisation of Tamil Eelam). Se le permitió volver al Reino Unido y nuevamente pidió asilo. Los casos de los señores Vaithialingam Skandarajah, Saravamuthu Sivakumaran, Vathanan Navratnasingam y Vinnasithamby Rasalinga, provenientes de SriLanka, que vivían una situación muy similar se acumularon. Todos los procesos de las segundas solicitudes de asilo siguen pendientes.

En esta ocasión, la Corte citó la subregla enunciada en las sentencias del caso Soering y el caso Cruz Varas. Luego hizo el examen de riesgo inminente en Sri Lanka para estas personas. Según la Corte el examen de la cuestión debía concentrarse en las consecuencias previsibles de la devolución de los demandantes a Sri Lanka, teniendo en cuenta la situación general en la isla en febrero de 1998 y las circunstancias propias de cada uno de ellos. El Tribunal consideró, en este sentido, que en dicha fecha la situación en el Norte y el Este de la isla había mejorado sensiblemente. En concreto, el programa de repatriación voluntaria del ACNUR, cuya ejecución comenzó a finales de 1987, mostró que en febrero de 1988 la situación era tal que permitió a numerosos tamiles regresar a Sri Lanka a pesar de la persistencia de problemas. Por esto la subregla que elucidó el Tribunal en este caso es que se si se tiene información oficial por medio de la cual se asegura que la situación en el país de origen ha mejorado sensiblemente, no hay fundamento para reconocer el estatus de refugiado. Para probar que la situación de riesgo del país de origen se ha estabilizado se debe tomar información oficial del país. Esto implica que el carácter objetivo del elemento de persecución debe ser analizado por las autoridades y de esta manera dar la protección solo a aquellos que sí son refugiados y lo necesitan.

\section{Caso Chahal c. Reino Unido. (Sentencia de 15 de julio de 1996)}

Los solicitantes, en este caso, fueron una familia compuesta por padre, madre y dos hijos nacidos en India, pertenecientes a la religión Sikh. En 1987 el padre y la madre pidieron la ciudadanía inglesa, la cual le fue negada al primero y la segunda no recibió respuesta. La Corte tuvo en cuenta que desde la partición de India, los Sikhs han estado inmersos en el proyecto político de conformar una tierra independiente en Khalistan, al lado de Punjab. Desde entonces se han presentado conflictos en esta zona, ya que las Fuerzas Armadas irrumpen en medio de ceremonias religiosas y otras actividades que implican la reunión de personas, para asesinar a los presentes. Luego de serle negada la ciudadanía en el Reino Unido, el señor Chahal vivió unas situaciones de persecución que lo llevaron a necesitar protección internacional. Fue así como el señor Chahal viajó a Punjab y fue bautizado para convertirse en Sikh. En esta estadía fue detenido por 21 días y sometido a tratos crueles e inhumanos. Luego se convirtió en una figura importante dentro de la religión Sikh, comenzó a participar en protestas y fue detenido por prevención contra el terrorismo. Viajó posteriormente al Reino Unido y allí fue detenido por conspiración y se ordenó su deportación alegando que su presencia reiterada en el Reino Unido 
era inconcebible para el bien público y para la seguridad nacional. Ante esto solicitó asilo y le fue negado, argumentando que las situaciones a las que hacía referencia habían sucedido hacía mucho, en un momento de más tensión en Punjab.

Teniendo estos hechos en cuenta, la Corte citó su jurisprudencia reiterada en el caso Vilvarajah, que fue mencionada por primera vez en el caso Soering, en el cual se dijo que el principio de no devolución se aplicaba al proteger el derecho consagrado en el artículo 3 del CEDH y que impide que una persona sea sometida a tratos inhumanos o crueles. Dijo entonces que

la prohibición del artículo 3 contra el trato cruel es igualmente absoluta en los casos de expulsión. Pero cuando quiera que hay sustento para creer que el individuo enfrenta un riesgo real de ser sometido a tratos contrarios al artículo 3 si es trasladado a otro Estado, surge la responsabilidad del Estado parte de salvaguardar a esta persona en el evento de prevenir la expulsión. En estas circunstancias, las actividades del individuo en cuestión, aunque sean no deseadas y peligrosas, no puede ser material de consideración. La protección del artículo 3 de la CEDH es mayor que la de los artículos 32 y 33 del Convenio del Estatuto de los Refugiado de las Naciones Unidas de 1951" (CEDH, Sentencia de 29 de abril de 1997, párr. 80).

Por esto la Corte concluyó que si se deportaba al señor Chahal se violaría el artículo 3, que no puede ser exceptuado por la posibilidad de peligro que implique la presencia de la persona en el Estado receptor. La subregla entonces es, que el principio de no devolución en caso de riesgo inminente de ser sometido a tratos crueles o muerte, es aplicado de manera absoluta bajo la protección del CEDH y los criterios de exclusión, como el de peligro para la seguridad nacional, no puede exceptuar este principio.

Esta providencia es excepcional, teniendo en cuenta que el artículo 33 del Estatuto del Refugiado de 1951 indica que la excepción al principio de no devolución es precisamente que la persona en cuestión represente un peligro para la seguridad nacional. En este caso la Corte Europea fue más allá, al darle un mayor alcance a la protección del derecho a no ser sometido a tratos crueles. Aunque esta subregla sea una excepción es relevante para el caso colombiano, debido a que evidencia la práctica de proveer más protección que la exigida por los convenios internacionales, por medio de jurisprudencia nacional.

\section{Caso HLR c. Francia. (Sentencia de 29 de abril de 1997)}

En este caso, un nacional colombiano, HLR, viajó de Colombia a Italia y fue detenido en el aeropuerto Roissy, en Francia, por poseer un paquete de 580 gramos de cocaína. Al ser interrogado el solicitante cooperó con información sobre el instigador del narcotráfico. Con esta información se identificó a dicha persona. HLR fue condenado por las cortes francesas a cinco años de prisión. Una vez terminó su condena se libró orden de deportación en su contra.

Ante estos hechos la Corte decidió que HLR no sufría un riesgo real puesto que no había prue- 
bas suficientes de que el cartel de drogas para el que trabajaba le hiciera daño una vez regresara a Colombia. Además no se probó que el Estado colombiano no lo pudiera proteger de estas amenazas. En esta decisión el Tribunal agregó una situación fáctica nueva: casos en los que el peligro provenga de personas o grupos de personas que no ejerzan una función pública; este riesgo también puede ser protegido por la prohibición de someter a alguien a torturas o tratos crueles e inhumanos. Este principio aplica inclusive cuando el Estado no es el persecutor, en virtud del carácter absoluto del derecho garantizado. Además, el Tribunal puso un requisito para su aplicabilidad, y es que deberá demostrarse que ese peligro existe realmente (real risk) y que las autoridades del Estado de destino no son capaces de proporcionar una protección apropiada.

\section{Caso D. c. Reino Unido. (Sentencia de 2 de mayo de 1997)}

El solicitante, nacido en San Cristóbal y Nieves, llegó a Estados Unidos en 1989 buscando a su familia y fue detenido el 5 de septiembre de 1991 por poseer cocaína, por lo cual fue condenado a tres años de prisión. Al año siguiente fue excarcelado por buena conducta y el 8 de enero de 1993 fue deportado a San Cristóbal y Nieves. Luego D. se fue a Londres donde solicitó la visa para turista de dos semanas, pero inmigración lo sorprendió con cocaína y por esta razón le fue negada la entrada. Fue condenado a seis años de prisión y mientras cumplía esta condena se le diagnosticó sida. Luego se le puso en libertad condicional y fue retenido para ser devuelto a
San Cristóbal y Nieves. El 23 de enero solicitó permiso de estadía por razones humanitarias arguyendo que si lo deportaban a su isla de origen perdería el beneficio del tratamiento médico del cual dependía su esperanza de vida. Esta solicitud fue rechazada.

Ante estos hechos el Tribunal tuvo en cuenta que en San Cristóbal solo existen dos hospitales donde puede tratarse el sida y únicamente de manera provisional hasta que los enfermos puedan ser atendidos por su familia. Consecuente con esto, el Tribunal agregó que el solicitante no tenía familia en San Cristóbal.

El Tribunal entonces decidió que sí existió violación del artículo 3 del Convenio Europeo, ya que la cesación de las prestaciones que el solicitante podía recibir en el Reino Unido tendría consecuencias graves, que le producirían sufrimientos físicos y psicológicos extremos. La Corte expresó que: "en vista de estas condiciones excepcionales y manteniendo en mente el estado crítico que ha alcanzado la mortal enfermedad del peticionario, la implementación de la decisión de enviarlo a San Cristóbal constituiría un tratamiento inhumano".

La subregla en este caso es que el principio de no devolución debe aplicarse cuando la deportación de la persona implique la cesación de un tratamiento médico que no puede recibir en el Estado de origen y que acarrea graves consecuencias para su salud. De esta manera, el Tribunal asoció una suspensión de tratamiento médico con tortura, ampliando el contenido del concepto. El Tribunal concluyó que deportar a un solicitante a un sitio donde no pueda acceder al 
tratamiento médico que requiere para sobrevivir es lo mismo que someterlo a una tortura y, por ende, se está violando la prohibición del artículo 3 del Convenio Europeo de Derechos Humanos.

\section{Caso Jabari c. Turquía. (Sentencia de 11 de julio de 2000)}

Hoda Jabari, de nacionalidad iraní, fue arrestada en Irán en octubre de 1997 por acusársele de adulterio, al tener relaciones íntimas con un hombre casado.

En febrero de 1998, huyó a Turquía con la intención de viajar a Canadá vía Francia, con un pasaporte canadiense falso. Sin embargo, fue detenida en Francia y enviada de regreso a Turquía, donde presentó una solicitud de asilo, la cual fue considerada inadmisible dado que excedió el límite de los 5 días de plazo para presentarla. Sin embargo, su recurso en contra de la orden de deportación a Irán ante el Tribunal Administrativo de Ankara fue declarado sin lugar. (ACNUR, resumen de Sentencia de 11 de julio de 2000, p. 1).

Frente a estos hechos el Tribunal conceptuó que

(...) la aplicación automática y mecánica de un plazo tan corto ( 5 días) para la presentación de solicitudes de asilo debe ser considerada en discordancia con la protección del valor fundamental consagrado en el artículo 3 del Convenio. La Corte Administrativa de Ankara, al realizar la revisión judicial, se limitó a analizar la legalidad de la deportación de la demandante más que los motivos sustanciales de sus temores, aunque para ese momento se debió haber considerado que ella tenía más que una petición discutible sobre el riesgo que enfrentaría en caso de ser enviada a su país de origen" (Sentencia 9 de julio de 2000, párr. 40).

Es así como el Tribunal estableció una nueva subregla: las solicitudes deben tener un rango más razonable de plazo para ser presentadas. Además, la revisión de las decisiones negativas frente al reconocimiento del estatus de refugiado debe tener la posibilidad de contemplar la base sustancial, no solo la procesal, para no caer en violaciones de los derechos de las personas, como el derecho al debido proceso. En este caso específico se violó el derecho a no ser sometido a tortura porque se comprobó la existencia de un riesgo real si el solicitante volvía a Irán.

\section{Caso Mubilanzila Mayeka and Kaniki Mitunga c. Bélgica. (Sentencia de 12 de octubre de 2006)}

En este caso se expulsó de Bélgica a Tabitha, una menor de edad, que viajaba con su tío. La menor fue abandonada por su tío a mitad del camino hacia Londres y, naturalmente, quedó sin acompañante en Bélgica. En este país fue detenida por las autoridades y posteriormente deportada por no tener papeles que legalizaran su entrada.

La Corte reiteró que el artículo 3 del Convenio Europeo no da lugar a excepciones, es absoluto: ninguna persona puede ser sometida a torturas. Mencionó en específico las necesidades de los menores de edad, por lo cual se deben considerar las particularidades de cada caso y la edad del menor: un niño de 16 es diferente de un niño de 5 años como Tabitha. Al hacer un 
examen de las medidas tomadas por el Estado de Bélgica, el Tribunal decidió que no fueron suficientes y por lo tanto se violó el artículo 3 del Convenio, puesto que la menor fue sometida a tortura al ser detenida.

Para determinar esta tortura el Tribunal recontó los hechos en los cuales la menor de 5 años estuvo retenida en Bélgica sin acompañante. Además, la menor tuvo dos abogados en menos de diez días y estos no estaban calificados para tratar niños. Dos meses después su deportación se hizo efectiva y la menor fue enviada a Kinsasha en avión, acompañada por una trabajadora del centro de tránsito. Al llegar al aeropuerto de Kinsasha, en la República Democrática del Congo, la menor fue dejada en manos de la policía debido a que ningún familiar fue a recogerla porque no había quién pudiera hacerse cargo de ella. Estuvo esperando sola por más de cinco horas. Además no se le permitió a la mamá contactarse con su hija.

Tras este análisis fáctico el Tribunal afirmó que la decisión de detener a un menor de edad y deportarlo también debe cumplir unos requisitos de debido proceso y el desplazamiento de este debe ser adecuado a los estándares internacionales. Si se lleva a cabo el proceso de deportación de un menor que no cumple los requisitos internacionales, $y$ al llegar al país de origen no existen las condiciones adecuadas para una persona de su edad, esto le genera un estado de ansiedad que constituye tortura. No se podía devolver a la niña en estas condiciones.

El Tribunal, aquí, dilucidó la subregla según la cual se puede deportar a un menor de edad, pero el proceso debe tener en cuenta su edad y su situación específica, considerando si a donde será deportado podrá ser recibido por familiares en condiciones que no violen el artículo 3 del Convenio Europeo.

\section{Conclusión sobre subreglas en el caso de la aplicación del principio de no devolución}

En sus providencias el Tribunal deja claro que la aplicación del principio de no devolución obedece a la protección del derecho a no ser sometido a tortura o tratos crueles e inhumanos, consagrado en el artículo 3 del Convenio Europeo, y afirma que su protección del derecho a no ser sometido a torturas ni a tratos crueles conlleva a una protección más amplia que la que provee la aplicación del principio de no devolución, debido a que la prohibición es absoluta y el principio no. La prohibición de torturas no puede ser suspendida, incluso en los casos en que peligre la seguridad nacional, en cambio en el principio de non refoulement el peligro a la seguridad nacional es la excepción que permite que se deje de aplicar. La autora considera que aunque el artículo 3 sea una excepción, vale la pena usar dicha subregla para entender la gran importancia de este principio y cómo la Comunidad Europea ha recurrido incluso a medidas extremas, para salvaguardar el derecho de los solicitantes de asilo a no ser sometidos a torturas ni tratos crueles.

Cuando el Tribunal protege este derecho impone un requisito: que se pruebe el riesgo inminente (real risk), es decir, que debe haber algún 
nivel de certeza de la posibilidad de sufrir tratos crueles e inhumanos o muerte si el solicitante regresa al país de origen. El Tribunal afirma que los riesgos no tienen por qué provenir del Estado como tal, pueden provenir de particulares pero se debe probar que el Estado no es capaz de dar al individuo la protección adecuada frente a este riesgo. Además, la Corte desarrolla la necesidad de dar especial trato a los menores de edad y cómo la devolución de estas personas debe ser muy cuidadosa y acorde con los estándares internacionales.

De lo anterior se puede inferir que la verdadera protección de la población vulnerable, que constituyen los refugiados, se da principalmente a partir de la aplicación del principio de no devolución, y el esfuerzo real por materializar esto está en hacer las normas regionales y nacionales más estrictas que las del derecho internacional de los refugiados como lo hizo el Sistema Europeo por medio del artículo 3 de su Convenio.

En los casos colombianos en que se expide una orden de deportación sin antes considerar la existencia de un riesgo real, se ve una clara violación de este principio. Esto nos lleva a sugerir: la adopción de estas subreglas para mejorar dicho procedimiento y evitar que todas las personas acudan a la acción de tutela para proteger este derecho; la necesidad de que el mismo procedimiento del reconocimiento del estatus de refugiado evalúe el riesgo presente antes de emitir una decisión; la armonía entre las decisiones del DAS y las del Ministerio de Relaciones Exteriores para no someter a la persona a una situación de inseguridad jurídica y no violar su derecho al debido proceso.
B. Privación ilegal de la libertad de solicitantes de asilo: retención bajo base legal poco garantizadora de Derechos Humanos, vista como violación al artículo 5 del Convenio para la Protección de los Derechos Humanos y de las Libertades Fundamentales (CEDH)

Colombia ha sido descrita por el Grupo de Trabajo sobre la Detención Arbitraria de las $\mathrm{Na}$ ciones Unidas (en adelante Grupo de Trabajo) como un país de tránsito al que la mayoría de personas inmigrantes ingresan para seguir su viaje hacia Estados Unidos. Entre estos flujos se encuentran refugiados que requieren una protección especial, pero debido a la dificultad de diferenciación a la que hace referencia el informe de Procuraduría (2011, p. 9): “los extranjeros encontrados en situación ilegal, sea por carecer de visado o por vencimiento de este, son detenidos para proceder a su expulsión”. (Grupo de Trabajo, 2009, párr. 93).

Teniendo en cuenta estos hechos, a continuación se analizará la jurisprudencia del Tribunal Europeo con el fin de establecer cómo puede asegurarse que el derecho a la libertad de estas personas no sea vulnerado como consecuencia de ingresos irregulares o de la dificultad para diferenciar los refugiados de otros flujos migratorios.

\section{Caso Amuur c. Francia. (Sentencia de 25 de junio de 1996)}

Cuatro solicitantes somalíes Ilegaron al aeropuerto de Orly, en París, procedentes de Siria, manifestando haber huido de Somalia debido 
a que sus vidas se encontraban en peligro. Los cuatro eran hermanos y declararon que algunos de sus familiares habían sido asesinados. A pesar de esto les negaron la entrada porque habían ingresado con documentos falsos y debieron permanecer detenidos en la zona de tránsito del aeropuerto Orly por veinte días. Los hermanos entonces solicitaron asilo, pero como no habían obtenido un permiso de residencia temporal las autoridades migratorias consideraron que la Oficina de Apátridas y Refugiados no tenía competencia sobre su caso. Posteriormente fueron devueltos a Siria sin haberles dado la oportunidad de presentar efectivamente una solicitud de asilo ante la mencionada Oficina de Protección.

Ante estos hechos, la Corte en su fallo expresó:

al contemplar que cualquier privación de libertad debe realizarse de conformidad con el procedimiento prescrito por la ley, el artículo 5, párrafo 1, principalmente establece que cualquier arresto o detención tenga una base legal en la legislación interna. Sin embargo, esta formulación no hace una simple referencia a la legislación interna (...), sino que también hace alusión a la calidad de la ley, un concepto inherente a todos los artículos del Convenio. (TEDH, sentencia de 25 de junio de 1996, párr. 50).

Profundizando en el significado de "calidad de la ley", el Tribunal expresó que "calidad" implica que sea una ley nacional la que autoriza la privación de libertad. Además, dicha ley debe ser aplicada teniendo en cuenta la situación especial de un solicitante de asilo para evitar cualquier riesgo de arbitrariedad. "Estas características tienen una importancia fundamental en relación con los solicitantes de asilo en los aeropuertos, particularmente en vista de la necesidad de reconciliar la protección de los derechos fundamentales con los requisitos contemplados en las políticas de inmigración de los Estados." (TEDH, sentencia de 25 de junio de 1996, párr. $50)$.

En esta forma la Corte enuncia la subregla que dice que la retención de solicitantes de asilo bajo condiciones dudosas y una base normativa de poca calidad constituye una violación a la libertad y, consecuentemente, al artículo 5 del Convenio.

\section{Caso Kadzoev c. Bulgaria (Sentencia de 11 de enero de 2012)}

En este caso el solicitante entró ilegalmente a Bulgaria y solicitó asilo al mes de su llegada, alegando que temía ser asesinado o torturado por el grupo militante islámico Jund al-Sham, ya que él pertenecía a la Organización para la Liberación Palestina, opositor a este grupo. Dos meses después de su llegada el solicitante intentó salir de Bulgaria con documentos falsos y fue capturado. Al mes le fue negada la solicitud de asilo pero le fue concedida la ayuda humanitaria. Al siguiente mes se solicitó su expulsión de Bulgaria alegando que representaba un peligro para la seguridad de este país, puesto que el solicitante era parte de un grupo terrorista Sunni; se libró orden de detención en su contra hasta que fuera deportado. Esto duró más de 18 meses.

Ante estos hechos el Tribunal alegó violación del artículo 13, debido a que el tiempo de espera fue desproporcionado y se debió suspender la 
captura mientras se decidía sobre la legalidad de su deportación.

La subregla en este caso sería que la decisión de detener personas que posteriormente solicitan asilo y se les niega, debe tener en cuenta la proporcionalidad del tiempo esperado, y que si se decide deportarlas, la ejecución de la orden no implique la violación del principio de no devolución. Mientras esto se define la persona no puede ser privada de su libertad ilegalmente. Esta ilegalidad puede surgir de la falta de una base legal o de la desproporción en el tiempo de espera.

Esta subregla debe ser aplicada en Colombia, considerando que la Corte Interamericana de Derecho Humanos exige que la detención de una persona tenga una base legal y que su ejecución no viole los derechos humanos del detenido (Corte IDH, 2010, párr. 98). Esto se ve de forma clara en el caso Vélez Loor c. Panamá, en el cual el señor Jesús Tranquilino Vélez Loor (ecuatoriano), fue retenido en el puesto policial de Tupiza, en la provincia del Darién, República de Panamá, el 11 de noviembre de 2002, por no portar la documentación necesaria para permanecer en dicho país. La Corte analizó el decreto que se usó para fundamentar la deportación y concluyó: que la detención del señor Vélez fue arbitraria porque no la hizo la autoridad migratoria competente (Corte IDH, 2010, párr. 111); que su retención también fue arbitraria porque no cumplió con las garantías del artículo 7 de la Convención Americana de Derechos Humanos; ${ }^{11}$

\footnotetext{
11 Artículo 7. Derecho a la Libertad Personal. Ver en: Op. cit. 4.
}

y que por ende la aplicación del decreto para retener al extranjero no fue legal. La subregla que enuncia es que debe haber una ley que soporte la detención, so pena de ser arbitraria. Esta subregla es obligatoria para Colombia debido a que la Corte IDH realiza la interpretación oficial de la Convención de San José de Costa Rica, de la cual Colombia hace parte.

\section{Conclusión sobre subreglas del respeto del derecho a la libertad en los casos de solicitantes de asilo}

El derecho a la libertad y el procedimiento de reconocimiento del estatus de refugiado tienen un punto de encuentro en el momento en que estas personas son detenidas por las autoridades migratorias del Estado receptor y no tienen en cuenta su especial vulnerabilidad. Los refugiados son confundidos con otros tipos de migrantes (económicos, por ejemplo) y a causa de esta confusión las autoridades no toman las medidas necesarias para asegurar la protección de estas personas. Las detienen bajo normas que no son aplicables a su caso, violando así su derecho a no ser restringidas en su libertad sin una base legal.

En este punto la jurisprudencia del Tribunal Europeo desarrolló el concepto de calidad de normas, según el cual no solo debe haber una norma que legalice la detención de la persona sino que debe ser una norma legal que proteja sus derechos y tenga suficiente calidad como para serle aplicada. De nuevo el Tribunal va más allá de las obligaciones respecto al derecho internacional de los refugiados, al requerir la calidad de 
las normas aplicables a la detención de personas en puntos migratorios.

Aunque parezca una protección expansiva por parte del Tribunal Europeo, Colombia debe aplicar esta subregla debido a que la Corte IDH, cuya jurisprudencia hace parte de la interpretación de la Convención Americana de Derechos Humanos, también exige la existencia de una norma legal. Además incluye este requisito de base legal en procedimientos administrativos y exige que la ejecución de una retención no viole derechos humanos de estas personas.

Otro criterio que analiza la Corte en casos de detenciones es el tiempo de la privación de la libertad y estatuye que este no puede ser desproporcionado y no puede durar mientras la situación del refugiado no se haya definido, ya que este procedimiento puede ser muy largo en algunos casos y la detención se volvería ilegal.

Por último, el Tribunal trata las condiciones de la detención: no puede darse en centros con poca higiene o donde las personas sean sometidas a malos tratos. Esto en garantía de que no se violen derechos humanos durante el tiempo de la detención y retención, lo cual es aplicable a Colombia gracias a la interpretación que ha hecho la Corte IDH del artículo 7 de la $\mathrm{CADH}$, obligatoria para nuestro país.

C. Violación al derecho al respeto de
la vida privada y familiar, en los casos
de solicitantes de asilo que se les niega
asilo a sus familiares, como violación al
artículo 8 del Convenio para la Protec-
ción de los Derechos Humanos y de las
Libertades Fundamentales (CEDH)

El derecho al respeto de la vida privada y familiar no se ha presentado como una problemática visible del procedimiento en Colombia, pero es un tema que ha sido tratado por el Tribunal Europeo de manera sistemática $\mathrm{y}$, por tanto, resulta relevante revisar estas subreglas. Aunque no se hayan presentado casos emblemáticos de este tipo, sí es necesario que el procedimiento en Colombia tenga en cuenta este derecho y cómo se armoniza con el derecho de los Estados a tener control migratorio, ejerciendo su soberanía. En el caso del señor Pirhadi, usado como ejemplo de los problemas de procedimiento en Colombia, también se abrió un proceso ante la jurisdicción administrativa, ante la cual el señor pidió que se pronunciaran sobre sus hijos y su esposa, quienes deberían reunirse con él y para esto se les debía reconocer el estatus de refugiados. Ante esta petición, el Consejo de Estado resaltó que el Ministerio hizo caso omiso de esta, lo cual demuestra la poca importancia que se le da al tema de la vida en familia en el procedimiento para el reconocimiento del estatus de refugiado (Consejo de Estado, 2005).

\section{Caso Gül c. Suiza. (Sentencia de 19 de febrero de 1996)}

En este caso, los señores Gül, que están en Suiza por razones humanitarias, son padres de Er- 
sin quien se encuentra en Turquía y piden que se permita el ingreso de su hijo a Suiza. El Tribunal dijo: "en vista del largo tiempo que el señor y la señora Gül han vivido en Suiza, en verdad no sería fácil para ellos regresar a Turquía, aunque, hablando estrictamente, no existen obstáculos que les impidan desarrollar una vida en familia en Turquía" (TEDH, Sentencia de 19 de febrero de 1996, párr. 42). En consecuencia, y poniendo de manifiesto no obstante la difícil situación en la que se encuentra la familia Gül desde el punto de vista humano, el Tribunal concluyó que Suiza no incumplió las obligaciones que le incumben en virtud del artículo 8.1 del Convenio Europeo.

La subregla en este caso fue que si bien se debe respetar el derecho a la vida en familia, el Tribunal debe valorar si dar asilo a los demás miembros es la única forma de mantener la unión familiar ya que de existir otra opción el Estado no está obligado a dar asilo a los familiares.

\section{Caso Mubilanzila Mayeka and Kaniki Mitunga v. Belgium. (Sentencia de 12 de octubre de 2006)}

Este caso fue mencionado al tratar el principio de no devolución debido a que la menor de edad fue sometida a tortura al ser devuelta a su país de origen. Así mismo se violó el derecho a la vida familiar por cuanto las autoridades belgas tomaron medidas que alargaron la reunión de la menor con su madre, en vez de ayudar a que este proceso se diera rápidamente teniendo en cuenta las necesidades de una menor de 5 años. Además, al detenerla la convirtieron en una menor no acompañada lo cual la ponía en situación de vulnerabilidad. El Estado belga tomó decisiones que impidieron el reencuentro de la madre con la hija. Incluso negó la solicitud del Departamento de Canadá de retener a la menor mientras se decidía sobre el reconocimiento del estatus de refugiado.

La subregla en este caso es que si bien un Estado puede usar la deportación con el fin de luchar contra la inmigración ilegal, no lo puede hacer en contravía de derechos como la vida en familia, en caso de que sus acciones impidan el goce de este derecho. El Estado no tiene el deber de reunir a las familias relajando sus políticas de inmigración, si hay otros medios que no requieran la acción del Estado. En el caso en que las acciones del Estado sean el único obstáculo para la ejecución del derecho a la vida en familia, este debe tomar las medidas necesarias para que puedan disfrutar de este derecho lo más pronto posible.

\section{Conclusión sobre subreglas del respeto del derecho a la vida privada y familiar en la solicitud de asilo}

En el caso del derecho a gozar de la vida en privado y en familia el Tribunal Europeo es menos protector, en comparación con los otros derechos analizados, debido a que considera que si bien el Estado no debe ser un impedimento para el goce de este derecho, no debe tomar medidas para que se materialice. Los Estados solo están obligados a proteger activamente este derecho en casos en que su acción sea la única vía. Esto implica, en lo atinente a los refugiados, que solo se debe reconocer el estatus de refugiado a fa- 
miliares que no tengan otra alternativa para vivir en familia, distinta a la del país receptor ante el que están pidiendo asilo. Debido a esto el Tribunal no reconoce frecuentemente el estatus de refugiado solo por el hecho de ser familiares. Lo importante para el Tribunal es que se demuestre que no se podrán reencontrar de otra forma que no sea siendo reconocidos como refugiados en dicho país. Es así como se impone una obligación de no hacer a los Estados para que se permita el goce del derecho a la vida en familia. Los casos en que los Estados sí deben tomar medidas son excepcionales, como el de Tabitha.

D. Violación al derecho a un recurso efectivo, como violación al artículo 13 del Convenio para la Protección de los Derechos Humanos y de las Libertades Fundamentales (CEDH), cuando el solicitante impugna la orden de deportación y no se suspende su ejecución ni se puede discutir el fondo de la decisión

Este tema ha sido objeto de muchas sentencias del Consejo de Estado y de la Corte Constitucional, cuando han determinado si se ha violado el debido proceso en el procedimiento para el reconocimiento del estatus de refugiado. Una situación común es que a la persona solicitante se le exijan pruebas específicas y plenas para demostrar su fundado temor, las cuales son difíciles de obtener. Un caso que refleja este problema es el del señor Pirhadi, quien interpuso recurso de reposición alegando que solo se le debían exigir pruebas sumarias. El Consejo de Estado decidió no reponer, por considerar que el solicitante no probó siquiera sumariamente el perjuicio que causaría su deportación. Posteriormente la
Corte Constitucional evidenció que sí había un riesgo y ordenó que se revocara la orden de deportación contra el sujeto. Lo anterior demuestra que las autoridades en Colombia, a veces, usan argumentos procesales para evadir analizar lo sustancial. La jurisprudencia del Tribunal Europeo puede ayudar a resolver este problema, pues indica el valor que se le debe dar a lo sustancial en todo el procedimiento, especialmente al recurrir una orden de deportación que podría poner en peligro la integridad de la persona.

\section{Caso Jabari c. Turquía. (Sentencia de 11 de julio de 2000)}

En el caso de la mujer acusada de adulterio, que ya fue mencionado en el desarrollo del principio de no devolución, también se violó el derecho al debido proceso. Según el Tribunal: “(...) la peticionaria fue capaz de cuestionar la legalidad de su deportación en un procedimiento de revisión judicial. Sin embargo, esta acción no le permitió suspender la ejecución de la deportación ni examinar el fondo de la solicitud que estaba en juego" (TEDH, sentencia de 11 de julio de 2000, párr. 49) y concluyó que:

(...) en consideración del carácter irreversible del daño que podría ocasionarse en caso de materializarse el presunto riesgo de tortura o malos tratos y por la importancia que la Corte le confiere al artículo 3, el concepto de un recurso efectivo bajo el artículo 13 requiere un escrutinio independiente y riguroso de la solicitud para esclarecer si existen razones para temer un verdadero riesgo de tratamientos contrarios al artículo 3 y la posibilidad de suspender la ejecución de la medida impuesta. (TEDH, sentencia de 11 de julio de 200, párr. 50). 
Por lo tanto, el Tribunal encontró que hubo una violación del artículo 13 del Convenio Europeo.

La subregla en este caso es que se debe poder revisar la decisión negativa frente a la solicitud de asilo de manera sustancial y no meramente procesal, ya que esto no protege los derechos de esta población vulnerable.

\section{Conclusiones sobre subreglas del res- peto del derecho a un recurso efectivo en la solicitud de asilo}

En esta sentencia la Corte dejó claro que el procedimiento de reconocimiento del estatus de refugiado no puede ser mediado de manera arbitraria y formal. Por la especial condición de vulnerabilidad de estas personas es necesario que se dé prioridad a lo sustancial y no a lo procesal. La consecuencia de esto es que se pueda debatir sobre el contenido de las solicitudes. El hecho que se permita la revisión de la decisión negativa frente al reconocimiento del estatus de refugiado no es suficiente por sí solo.

\section{CONCLUSIONES}

En Colombia el procedimiento para el reconocimiento del estatus de refugiado parece no tener en cuenta que el fin último de este es garantizar el derecho fundamental al asilo. Esta ignorancia se evidencia en los vacíos y falencias del Decreto 4503 del 2009 y en los errores cometidos a nivel nacional en las resoluciones sobre diferentes solicitudes de refugio. La gravedad de estos se refleja en la falta de protección de otros derechos de igual importancia como el debido proceso, la igualdad y la integridad personal (prohibición de tortura y malos tratos). En consecuencia, el procedimiento en Colombia requiere de criterios que ayuden a mejorar esta práctica, buscando que el derecho fundamental al asilo se materialice efectivamente en las resoluciones de las solicitudes de asilo.

La jurisprudencia del TEDH, ante todo, resalta la exigencia de proteger los derechos fundamentales del solicitante de asilo, más allá del interés del Estado en el que se encuentra. Por eso sus subreglas, además de proveer criterios útiles para solucionar los vacíos del Decreto colombiano, señalan el criterio básico que debe tener tanto el marco legal como la acción de los funcionarios responsables del procedimiento de asilo, que no es otro que la garantía de los derechos en juego.

Para proteger estos derechos, el Sistema Europeo de Derechos Humanos ha hecho que se cumplan las disposiciones de la Convención de 1951 sobre el Estatuto de los Refugiados, partiendo de violaciones al Convenio Europeo. En la revisión de la jurisprudencia de este Tribunal se encontró que la mayoría de quejas que se presentan se dan por violación al artículo 3 del Convenio, el cual prohíbe la tortura.

Las subreglas usadas por este tribunal intergubernamental en casos de refugiados podrían ser aplicadas por Colombia, dando mayor importancia a lo sustancial sobre lo procesal y haciendo salvaguardar los derechos de los solicitantes de refugio, lo cual no solo los beneficiaría sino que les garantizaría una mayor protección. De este modo, se estaría realizando el fin del Estado social de derecho en cuanto a proteger los 
derechos fundamentales de las personas, tanto a nivel formal como material.

También es muy importante analizar caso por caso y no aplicar fórmulas a grupos de personas sin estar seguros de que un caso es idéntico a otro. Es necesario valorar cada requisito de inclusión y cada criterio de exclusión dados por la Convención de 1951 de manera cuidadosa, dándole prioridad a la historia particular del solicitante pero sin olvidar el contexto del país de origen. Esta recomendación se debe aplicar en aras de salvaguardar el derecho a la igualdad y seguir la prohibición de discriminación.

Por otro lado, es necesario tomar medidas para que el principio de no devolución, pilar esencial del derecho de refugiados, se cumpla. Los mecanismos usados por el Sistema Europeo deben ser tomados como ejemplo, ya que además de lo dispuesto por la Convención de 1951, cuenta con normas que le dan más fuerza como el artículo 3 del Convenio Europeo, el cual es más proteccionista que el mismo principio. Las subreglas analizadas podrían ayudar a que nuestros funcionarios, en vez de la práctica generalizada de negar el reconocimiento de la condición de refugiados, asuman como regla la protección a favor de estas personas. En consecuencia, es necesario hacer una revisión del Decreto 4503 de 2009, buscando que los funcionarios tengan un verdadero entendimiento de lo que implica la condición de refugiado. Para conseguir esto, también se requiere capacitar a los agentes encargados del control migratorio en las fronteras y a los funcionarios del Ministerio para que aprendan a diferenciar entre migrantes económicos y refugiados.
Por último, se debería incentivar la obligatoriedad de las entrevistas, con una previa capacitación en la cual se deje claro que lo más importante es la coherencia del solicitante y no su aspecto ni su procedencia, entre otros criterios que se usan como argumento de discriminación. Esta obligatoriedad aseguraría la protección del derecho al debido proceso y haría que las decisiones tomadas por el Ministro, a partir de las recomendaciones de la Comisión Asesora, estén bien motivadas.

Todas estas recomendaciones deben ser aplicadas teniendo en cuenta que la mayor falencia en el procedimiento es la falta de sensibilidad de los funcionarios frente a la condición de refugiados. Es necesario que estas personas entiendan que la protección a los refugiados es una forma de realizar los fines del Estado social de derecho, uno de ellos, la protección de los derechos fundamentales de las personas. La base de estos derechos fundamentales son los derechos humanos, que tienen un carácter universal, y este carácter se debe tener presente en el trato a los refugiados que recibe Colombia y a quienes solicitan dicho estatus. Una vez se consiga esta sensibilización, las decisiones de los funcionarios estarán encaminadas a proteger los derechos de esta población y no a resolver las solicitudes con el criterio de aplicar un filtro migratorio.

\section{Bibliografía}

ACNUR. (1979, reeditado en 1992). Manual de procedimientos y criterios para determinar la condición de refugiado en virtud de la Convención de 1951 y el Protocolo de 1967 sobre el Estatuto de los Refugiados. Recu- 
perado el 30 de agosto de 2011 en: http:// www.acnur.org/t3/fileadmin/scripts/doc. php?file=biblioteca $/$ pdf $/ 0626$

ACNUR. (2001). Interpretación del artículo 1 de la Convención sobre el Estatuto de los Refugiados. Extraído en agosto de 2011 de: www. acnur.org/biblioteca/pdf/2553.pdf

ACNUR. (2006). El ACNUR y la protección internacional: programa de iniciación a la protección. Extraído el 25 de agosto de 2011 de: http:// www.acnur.org/t3/fileadmin/scripts/doc. php?file=biblioteca/pdf/4262

ACNUR. (2007). Cátedra Manuel Ancízar "Categorías y definiciones sobre las migraciones, el refugio internacional y el desplazamiento forzado". Bogotá.

ACNUR. (2000). La situación de los refugiados en el mundo 2000. Cincuenta años de acción humanitaria. Icaria Editorial, Ausias Marc, 16. $3^{\circ}, 2^{\mathrm{a}}$, 08010. Barcelona.

Consejo de Derechos Humanos de las Naciones Unidas. (2009). Informe del Grupo de Trabajo sobre la Detención Arbitraria. Adición Misión a Colombia. A/HRC/10/21/Add. 3 de febrero de 2009.

Colombia. Consejo de Estado. (2005). Sentencia tres (3) de noviembre de dos mil cinco (2005). Radicación número: 11001-03-24000-2004-00210-01.

Colombia. Corte Constitucional. (1996). Sentencia T-186. Magistrado Ponente: Vladimiro Naranjo Mesa. Referencia: expediente L.A.T. 049.
Colombia. Corte Constitucional. (2000). Sentencia C-010. Magistrado Ponente: Alejandro Martínez Caballero. Referencia: expediente D-2431.

Colombia. Corte Constitucional. (2003). Sentencia T-704. Magistrado Ponente: Clara Inés Vargas Hernández. Referencia: expediente T-738454.

Colombia. Presidencia de la República. (2009). Decreto Ley 4503 del noviembre 19 del 2009.

Colombia. Procuraduría General de la Nación. (2011). Informe en materia de asilo y recomendaciones para la creación de la línea de intervención de la Procuraduría General de la Nación en esta materia. Procuraduría delegada para la prevención en materia de derechos humanos y asuntos étnicos. Grupo de desplazamiento forzado y refugio. Bogotá.

Consejo de Europa. (1950). Convenio para la Protección de los Derechos Humanos y de las Libertades Fundamentales. Roma, el 4 de noviembre de 1950.

Corte Interamericana de Derechos Humanos. (2012). Caso Vélez Loor c. Panamá. Sentencia de 23 de noviembre de 2010. (Excepciones Preliminares, Fondo, Reparaciones y Costas).

El Tiempo. (2008). La historia de un etíope que se refugió en Colombia muestra el drama de quienes dejan su país. Recuperado el 28 de mayo de 2012 de: http://www.eltiempo.com/ archivo/documento/CMS-4330205 
EXсом. (1997). Conclusión general No. 6 (XXVIII), párr. A.

NaCIONES UnidAs. (1951). Convención de 1951 sobre el Estatuto de los Refugiados. Adoptada en Ginebra, Suiza, el 28 de julio de 1951 por la Conferencia de Plenipotenciarios sobre el Estatuto de los Refugiados y de los Apátridas.

Parlamento de Europa, Consejo de la Unión Europea y Comisión EuRopea. (2001). Carta de Derechos Fundamentales de la Unión Europea. (2000/C 364/01), Niza, 7 de diciembre de 2001.

Tribunal Europeo de Derechos Humanos. (1996). Sentencia 26 de octubre de 1996. Caso Ahmut c. Países Bajos, n²1702/93.

Tribunal Europeo de Derechos humanos. (1996). Sentencia de 15 de noviembre de 1996. Caso Chahal c. Reino Unido, n²2414/93.

Tribunal Europeo de Derechos Humanos. (1996). Sentencia de 25 de junio de 1996. Caso Amuur c. Francia, nº 19776/92.

Tribunal Europeo de Derechos humanos. (2000). Sentencia de 11 de julio de 2000. Caso Jabari c. Turquía, n. ${ }^{\circ}$ 40035/98.

Tribunal Europeo de Derechos Humanos. (2000). Sentencia de 11 de julio de 2000. Caso Ciliz contra los Países Bajos, n. ${ }^{\circ}$ 29192/95.

Tribunal Europeo de Derechos Humanos. (2000). Sentencia de 11 de julio de 2000. Caso Jabari c. Turquía, n. ${ }^{\circ}$ 40035/98.
Tribunal Europeo de Derechos Humanos. (2001). Sentencia de 6 de febrero de 200. Caso Bensaid c. el Reino Unido, n. ${ }^{\circ} 44599 / 98$.

Tribunal Europeo de Derechos Humanos. (2001). Sentencia de 6 de marzo de 2001. Caso Hilal c. Reino Unido, n. ${ }^{\circ} 45276 / 99$.

Tribunal Europeo de Derechos humanos. (2012). Sentencia de 2 de enero de 2012. Caso Kadzoev c. Bulgaria, n. ${ }^{\circ}$ 46390/10.

Tribunal Europeo de Derechos Humanos. (1989). Sentencia de 7 de julio de 1989. Caso Soering c. Reino Unido, n. ${ }^{\circ} 14038 / 88$.

Tribunal Europeo de Derechos Humanos. (1991). Sentencia de 20 de marzo de 1991. Caso Cruz Varas y otros c. Suecia, n. ${ }^{\circ}$ 15576/8.

Tribunal Europeo de Derechos Humanos. (1991). Sentencia de 30 de octubre de 1991. Caso Vilvarajah y otros c. Reino Unido. Acumulación de casos: n. ${ }^{\circ}$ 13163/87, 13164/87, $13165 / 87,13447 / 87$ y $13448 / 97$.

Tribunal Europeo de Derechos Humanos. (1996). Sentencia de 19 de febrero de 1996. Caso Gül c. Suiza, n. ${ }^{\circ}$ 23218/94.

Tribunal Europeo de Derechos Humanos. (1997). Sentencia de 2 de mayo de 1997. Caso D. c. Reino Unido, n. ${ }^{\circ}$ 30240/9.

Tribunal Europeo de Derechos humanos. (1997). Sentencia de 29 de abril de 1997. Caso H.L.R. c. Francia, n. ${ }^{\circ}$ 24573/94. 